\title{
EVALUATION OF ANTIBIOTIC USE IN 2018 AT THE KEBAYORAN BARU PRIMARY HEALTH CARE, INDONESIA, USING THE ANATOMICAL THERAPEUTIC CHEMICAL/DEFINED DAILY DOSE METHOD
}

\author{
LARASATI ARRUM KUSUMAWARDANI, ATIKA WAHYU PUSPITASARI*, VANNISA NABILLA WIDYANTARI \\ Clinical Pharmacy Laboratory, Faculty of Pharmacy, Universitas Indonesia, Depok, Indonesia. Email: atikawp.mi@gmail.com
}

Received: 26 September 2019, Revised and Accepted: 17 December 2019

ABSTRACT

Objective: The abnormally high use of antibiotics can indicate irrational prescribing. One of the ways by which to support rationally prescribing antibiotics is by evaluating their frequency of use. This study aimed to evaluate the use of antibiotics in 2018 by outpatients at the Kebayoran Baru Primary Health Care of Indonesia.

Methods: The study was a cross-sectional and descriptive design. Data were collected retrospectively from sampling outpatient records. The data were on oral antibiotics prescribed in 2018 at Kebayoran Baru Primary Health Care. There were 10,553 prescriptions for oral antibiotics used as the study samples. Both quantitative and qualitative evaluations were conducted. The quantitative evaluations were conducted using the method recommended by the World Health Organization, namely, the anatomical therapeutic chemical/defined daily dose (DDD), and the qualitative evaluations were conducted using the 90\% drug utilization (DU 90\%) method and the suitability of antibiotic use with the list of drugs in the Indonesian national formulary for the first-level health facilities (FKTP).

Results: Three of the antibiotics used most often were amoxicillin at 0.9358 DDD/1000 inhabitants/d, ciprofloxacin at 0.4940 DDD/1000 inhabitants/d, and cefadroxil at $0.1983 \mathrm{DDD} / 1000$ inhabitants/d. The drugs within the DU 90\% segment were amoxicillin, ciprofloxacin, cefadroxil, and thiamphenicol. There was 70\% compatibility of antibiotic use with Indonesian national formulary for the FKTP.

Conclusion: We suggest that the use of antibiotics at Kebayoran Baru Primary Health Care tended to be on the high side and not in accordance with national guidelines.

Keywords: Antibiotics, Anatomical therapeutic chemical/defined daily dose, 90\% drug utilization method, Evaluation of drug use, the Indonesian national formulary.

(c) 2020 The Authors. Published by Innovare Academic Sciences Pvt Ltd. This is an open access article under the CC BY license (http://creativecommons. org/licenses/by/4. 0/) DOI: http://dx.doi.org/10.22159/ijap.2020.v12s1.FF011

\section{INTRODUCTION}

An antibiotic is a compound that can effectively inhibit the growth of microorganisms [1]. Antibiotics are used to prevent and treat infectious diseases caused by bacteria [2]. Infectious disease is a major contributor to death in developed and developing countries; therefore, it becomes one of the most critical public health problems [3,4]. Indonesia Basic Health Research 2018 has shown that acute respiratory infections (ARIs) have the highest prevalence of all infectious diseases at $9.3 \%$, followed by others such as pneumonia (4.0\%), diarrhea (7.0\%), hepatitis $(0.4 \%)$, tuberculosis $(0.4 \%)$, and malaria $(0.4 \%)$ [5].

Irrationally prescribing these antibiotics can lead to their excessive use [6]. For example, research in the United States in 2010-2011 has indicated that $\sim 30 \%$ of the antibiotics prescribed on an outpatient basis are aimed at infectious diseases for which antibiotics are not necessary, such as diseases caused by viruses [7]. Research from the Antimicrobial Resistance in Indonesia study in 2000-2005 on 2494 people within community has shown that as many as $43 \%$ of Escherichia coli are resistant to the antibiotics ampicillin (34\%), cotrimoxazole (29\%), and chloramphenicol (25\%) [8]. In addition, in 2013, the WHO reported a mortality rate from bacterial resistance as high as 700,000 people per year. This mortality rate is expected to continue to increase to 10 million people per year by 2050 [9]; therefore, to minimize the risk of increasing resistance and to support the rational use of antibiotics, their use must be monitored and evaluated using structured and sustainable methods. Evaluation of regular antibiotic use can provide an overview of use patterns [10]. The evaluation of antibiotic use in this study was conducted by applying the anatomical therapeutic chemical/defined daily dose (ATC/DDD) and 90\% drug utilization (DU 90\%) methods.

The ATC/DDD classification systems for measuring units are tools used to exchange and compare data on drug use at the local, national, and international levels to improve the quality of drug use [11]. This method can also be used to detect the early signs of irrational drug use [12].

The DU 90\% method group drugs fall into categories that indicate that they comprise $90 \%$ of the most-used drugs. The two methods can be combined to identify segments of high drug use and can be used to determine the possibility of their irrational use by identifying either their underuse or overuse $[12,13]$.

Conformity with national formulary is also evaluated as an indicator of the quality of prescribing. Using Indonesian national formulary as a guideline for drug use helps to ensure rational and appropriate drug consumption [14]. Conformity with these guidelines can also be used to compare the quality of prescribing among health facilities and among regions [15].

\section{METHODS}

This study was conducted using a cross-sectional research design and retrospectively collecting data. The data used in the study are secondary data in the form of patient prescriptions from Kebayoran Baru Primary Health Care in 2018. The study was conducted from January to June 2019. Data were retrieved in April 2019. The sample used in this study is the protocol for the inclusion criteria for oral antibiotic prescriptions 
for adult patients' ages 18-59 years in March-December. The exclusion criterion in this study was incomplete oral antibiotic prescription sheets (i.e. data sheets that did not include the date of the prescription, name of the drug, amount of the drug, strength of drug, drug dosage, or prescribed dose). The study has received a research permit from Unit Pelaksana Pelayanan Terpadu Satu Pintu, Kota Administrasi Jakarta Selatan by number 421/082.61.

Both quantitative and qualitative measures were used to evaluate the data. Quantitative evaluation used methods recommended by the WHO and ATC/DDD qualitative evaluation used the DU $90 \%$ method and antibiotic use suitability based on the list of drugs in Indonesian national formulary for the first-level health facilities (FKTP).

\section{RESULTS AND DISCUSSION}

Groups and types of antibiotics used at Kecamatan Kebayoran Baru Primary Health Care

Ten types of antibiotics were used at Kebayoran Baru Primary Health Care in 2018. Complete data on the groups and types of antibiotics used are listed in Table 1.

As shown in Table 1, amoxicillin was the most prescribed antibiotic at $46.68 \%$ and had the highest DDD value at 20,462 . This value reflects that 20,462 average daily doses of this antibiotic were used within one period of time at the Kebayoran Baru Primary Health Care. Amoxicillin is often prescribed because it has a broad spectrum of activity and is commonly used for empirical therapy (infections of unknown bacterial types and their causes) $[16,17]$.

Certain infections, especially ARIs, which were the disease with the highest prevalence in 2018 at Kebayoran Baru Primary Health Care, are responsible for the high number of amoxicillin prescriptions. ARIs include non-specific (i.e., caused by several types of organisms) acute pharyngitis, acute nasopharyngitis, and acute upper respiratory tract infections. ARI sufferers in 2018 comprised $16.02 \%$ of the total patients who visited the hospital. The results of this study are in accordance with ARI management, which states that amoxicillin is one of the first lines of defense that can be used against ARIs, such acute pharyngitis that is caused by a Group A Streptococcus pathogen (e.g., Streptococcus pyogenes) and other Streptococcus species. The 2007 guidelines for basic medicine at the primary health care also mentioned that in addition to the erythromycin and cotrimoxazole, amoxicillin is another option that can be used to treat acute pharyngitis.

The results of this study are similar to those of a 2010 study conducted at a health services facility in Bandung that has shown that amoxicillin is often used on patients suffering from respiratory infections, which is $70.3 \%$ of the antibiotics used amoxicillin [16]. Research at three primary health care in the Depok area - Cipayung, Limo, and Bojongsari Primary Health Care - in 2016 has also shown that amoxicillin is the most commonly used antibiotic against ARIs [14].

Ciprofloxacin is the second most commonly used antibiotic at a prescription rate of $20.28 \%$. Table 1 presents the data on its use and shows that ciprofloxacin had a value of 10,802 DDD, which means that 10,802 average daily doses of this antibiotic were used within one period of time at Kebayoran Baru Primary Health Care. Ciprofloxacin is the second-generation fluoroquinolone antibiotic that exhibits good antibacterial activity. It is also extensively used to treat bacterial infections when the cause is unknown due to its broad-spectrum activity, oral efficacy, and high tolerability [18]. Ciprofloxacin is used to treat various bacterial infections, including upper and lower respiratory tract infections, some skin infections, bone infections, soft tissue infections, and community-acquired pneumonia [18]. Other clinical evidence has stated that ciprofloxacin shows increased efficacy in urinary tract infections and sexually transmitted diseases [18].

Cefadroxil is the third most commonly used antibiotic at a prescription rate of $16.10 \%$. Table 1 data show that cefadroxil had a value of 4335.75 DDD, which ranks it among the top three most commonly used antibiotics to treat infections. Cefadroxil is the first-generation cephalosporin that is effective against Gram-positive bacteria but has moderate activity against Gram-negative bacteria [3].

\section{DDD/1000 inhabitants/d}

Drug use data expressed in DDD/1000 inhabitants/d provide a measure of exposure or therapeutic intensity in a population to allow comparisons among various time periods and population groups [11]. The value of DDD/1000 inhabitants/d determines the percentage of the population who receive the drug within a certain period of time. Table 2 presents the results of calculations on antibiotic use based on DDD/1000 inhabitants/d.

Table 1: Groups and types of antibiotics used at Kebayoran Baru Primary Health Care in 2018

\begin{tabular}{llll}
\hline No. & Group & Types of antibiotics & Number of recipes (n=10,803) \\
\hline 1. & Penicillin & Amoxicillin & 5043 \\
2. & Florokuinolon & Ciprofloxacin & 2191 \\
3. & Generation I losporins & Cefadroxil & 1739 \\
4. & Nitroimidazole & Metronidazole & 723 \\
5. & Amphenicol & Thiamphenicol & 318 \\
6. & Macrolides & Azithromycin & 297 \\
7. & Sulfamethoxazole-trimethoprim & Cotrimoxazole & 276 \\
8. & Generation III cephalosporins & Cefixime & 111 \\
9. & Macrolides & Erythromycin & 103 \\
10. & Tetracycline & Doxycycline & 2.69 \\
\hline
\end{tabular}

Table 2: DDD and DDD/1000 inhabitants/d of antibiotics at Kebayoran Baru Primary Health Care

\begin{tabular}{|c|c|c|c|c|c|c|}
\hline Antibiotic & ATC code & DDD unit (g) & Value maid service & DDD/1000 inhabitants/day & Percentage & Cumulative percentage \\
\hline Amoxicillin & J01CA04 & 1.5 & 20,462 & 0.9358 & 48.79 & 48.79 \\
\hline Ciprofloxacin & J01 MA02 & 1 & 10,802 & 0.4940 & 25.76 & 74.55 \\
\hline Cefadroxil & J01DB05 & 2 & 4335.75 & 0.1983 & 10.34 & 84.89 \\
\hline Thiamphenicol & J01BA02 & 1.5 & 1835.67 & 0.0840 & 4.38 & 89.27 \\
\hline Metronidazole & $\mathrm{P} 01 \mathrm{AB} 01$ & 2 & 1709.75 & 0.0782 & 4.08 & 93.35 \\
\hline Azithromycin & J01FA10 & 0.3 & 991.67 & 0.0454 & 2.36 & 95.71 \\
\hline Erythromycin & J01FA01 & 1 & 968.5 & 0.0443 & 2.31 & 98.02 \\
\hline Cefixime & J01DD08 & 0.4 & 111 & 0.0051 & 0.26 & 99.93 \\
\hline \multirow[t]{2}{*}{ Doxycycline } & J01AA02 & 0.1 & 28 & 0.0013 & 0.07 & 100 \\
\hline & Total & & $41,937.59$ & 1.9181 & 100 & \\
\hline
\end{tabular}

DDD: Defined daily dose, ATC: Anatomical therapeutic chemical 
The results of this study indicate that the total use of antibiotics at Kebayoran Baru Primary Health Care was 1.9181 DDD/1000 inhabitants/d, which also indicates that as many as $0.19 \%$ of the total population received antibiotics during the study period or that in each day during the study period, 2 out of 1000 adult patients received antibiotics.

Amoxicillin had a value of 0.94 DDD/1000 inhabitants/d, which indicates that $\sim 0.1 \%$ of the total population received amoxicillin antibiotics during the study period. Ciprofloxacin had a value of 0.49 DDD/1000 inhabitants/d, which indicated that $\sim 0.05 \%$ of the population received ciprofloxacin during the study period. Cefadroxil had a value of $0.095 \mathrm{DDD} / 1000$ inhabitants/d, which indicated that $\sim 0.01 \%$ of the population received cefadroxil during the study period

The results of this study based on DDD/1000 inhabitants/d compared to those of research at the primary health care in Limo, Cipayung, and Bojongsari in 2016 indicate a higher rate of antibiotic use at primary health care in the Kebayoran Baru. The total use of antibiotics at primary health care in Limo was 0.76 DDD/1000 inhabitants/d. These results can also be interpreted to mean that $\sim 0.08 \%$ of the total population received antibiotics during the study period. The most commonly prescribed antibiotics for ARI patients at primary health care are amoxicillin with a lower value of $0.28 \mathrm{DDD} / 1000$ inhabitants/d $(0.03 \%)$, ciprofloxacin at $0.07 \mathrm{DDD} / 1000$ inhabitants/d $(0.007 \%)$, and cefadroxil at $0.095 \mathrm{DDD} / 1000$ inhabitants/d (0.01\%). The total use of antibiotics at primary health care in Cipayung was 0.95 DDD/1000 inhabitants/d, which indicated that $\sim 0.1 \%$ of the total population received antibiotics during the study period. The total use of antibiotics at primary health care in Bojongsari was 0.65 DDD/1000 inhabitants/d, which indicated that $\sim 0.07 \%$ of the total population received antibiotics during the study period.

The results of this study indicate that the use of antibiotics at Kebayoran Baru Primary Health Care in 2016 tended to be higher than that at primary health care in Limo, Cipayung, or Bojongsari Depok. These different results could be attributed to the fact that our study considered overall antibiotic use, while the study at primary health care in Limo considered only antibiotics indicated for ARI patients.

The graph in Fig. 1 shows the pattern of antibiotic use at primary health care in the Kebayoran Baru in 2018 each month during the study period. Based on the graph, amoxicillin, ciprofloxacin, and cefadroxil consistently ranked among the top three antibiotics used each month.
Amoxicillin use decreased in June, September, November, and December, which could be the result of a reduction in the number of patients with respiratory disease, which has the highest prevalence of all infectious diseases at the primary health care. The use of ciprofloxacin tends to decrease from March to December, which could be the result of a decrease in the number of patients who were prescribed ciprofloxacin and a decrease in the amount of ciprofloxacin in stock. Cefadroxil use from March to December tended to be stable; however, there was a significant increase in its use in August. Based on interviews with head pharmacists, cefadroxil was given to patients who did not respond to amoxicillin; therefore, the increased use of cefadroxil during that month could be the result of an increase in the number of patients who did not respond to previous amoxicillin therapy.

Four out of the 10 antibiotics (40\%) (i.e., amoxicillin, ciprofloxacin, cefadroxil, and thiamphenicol) were included in the DU 90\% segment list for the patients at Kebayoran Baru Primary Health Care in 2018. The percentage of antibiotic use included in the DU $90 \%$ segment is shown in Fig. 2.

These results are similar to those from the research conducted at 14 primary health care in North Gorontalo. Antibiotics that were included in the DU 90\% segment in North Gorontalo were amoxicillin, ciprofloxacin, and cefadroxil [19].

The number of antibiotics that have many variations creates the potential for an increase in antibiotic resistance. Thus, antibiotics that are included in the DU 90\% segment must be evaluated for their rational use to minimize the risk of resistance [20]. The identification of an antibiotic in the DU $90 \%$ segment can also be used as planning data for providing drugs for the next time period and predicting the side effects of the drugs most frequently used [12].

\section{Conformity of antibiotic use with the Indonesian national formulary for the FKTP}

Conformity with the Indonesian national formulary is an indicator of the quality of drug use. Using Indonesian national formulary as a guideline helps to ensure rational and appropriate drug consumption [14].

At primary health care in the Kebayoran Baru, there is $70 \%$ conformity of antibiotic use to Indonesian national formulary and the remaining $30 \%$ is incompatible due to prescriptions of azithromycin, thiamphenicol, and cefixime, which are not in accordance with Indonesian national

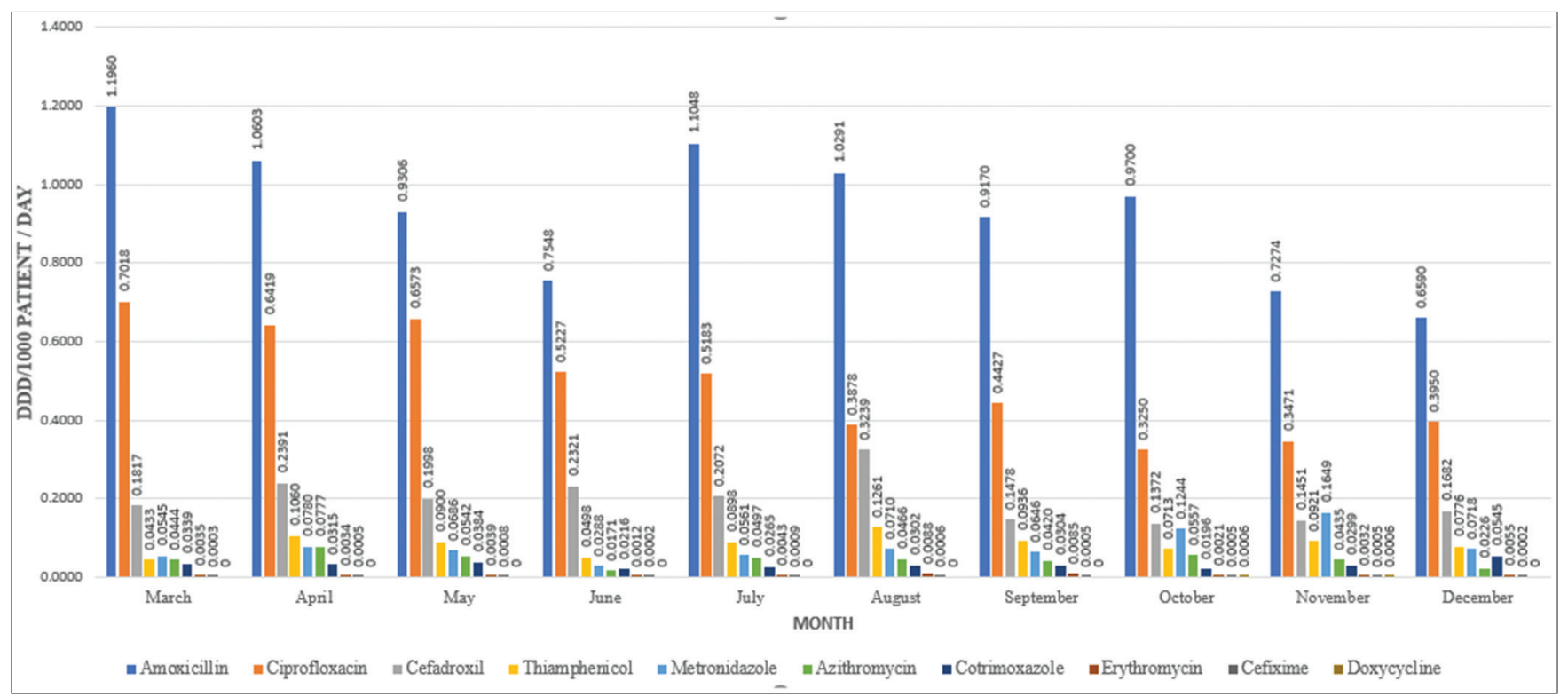

Fig. 1: Antibiotic use patterns in the defined daily dose/1000 inhabitants/d $90 \%$ drug utilization 


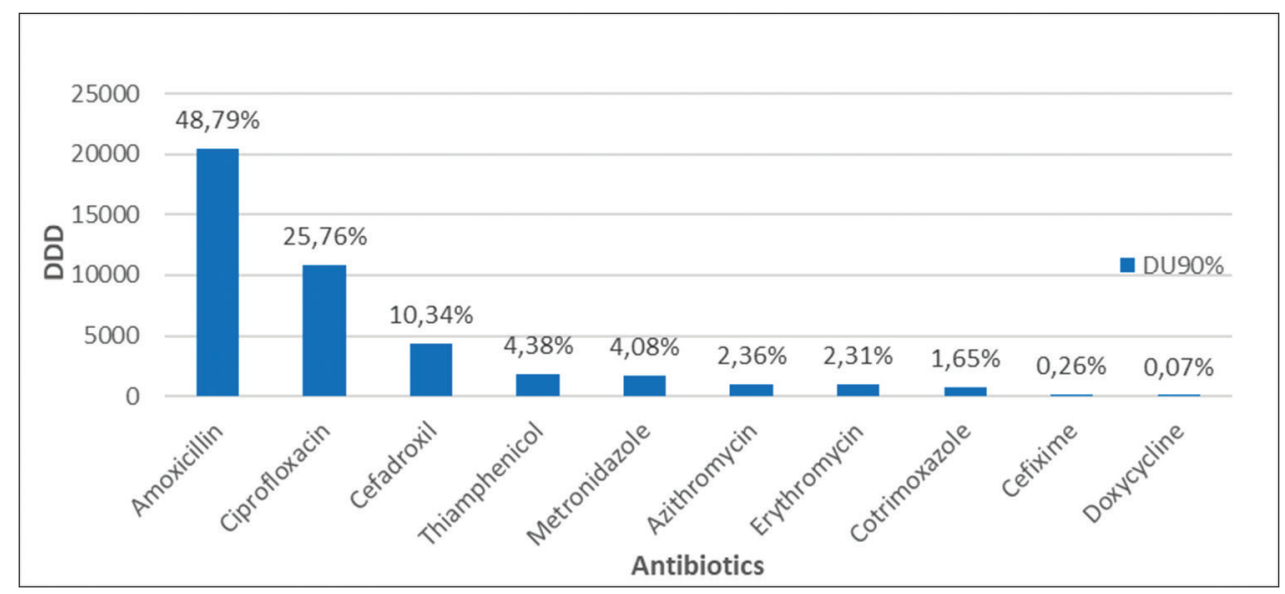

Fig. 2: Percentage of antibiotic uses included in the $90 \%$ drug utilization segment

Table 3: The percentage of conformity of antibiotic use with the Indonesian national formulary for the FKTP

\begin{tabular}{ll}
\hline $\begin{array}{l}\text { Conformity to the Indonesian } \\
\text { national formulary for FKTP }\end{array}$ & Total (\%) \\
\hline Compatible & $7(70)$ \\
Incompatible & $3(30)$ \\
Total & $10(100)$ \\
\hline FKTP: First-level health facilities
\end{tabular}

FKTP: First-level health facilities

formulary guidelines for the FKTP (Table 3). These results suggest that the use of antibiotics at Kebayoran Baru Primary Health Care is not in accordance with Indonesian national formulary.

Kebayoran Baru Primary Health Care uses thiamphenicol, even though it is not in accordance with the list of drugs in Indonesian national formulary, thiamphenicol is included in the 2007 Basic Care Health Center Guidelines. Thiamphenicol is a chloramphenicol analog that has a broad-spectrum activity similar to that of chloramphenicol but less active. Thiamphenicol does not cause the chloramphenicol side effect of aplastic anemia. Based on the results of interviews conducted with the chief pharmacist at Kebayoran Baru Primary Health Care, thiamphenicol is currently prescribed as a therapeutic option by doctors for patients with indications of typhoid fever. These results are in accordance with the 2007 Basic Care Health Center Guidelines. These guidelines state that, in addition to chloramphenicol and ampicillin, thiamphenicol is another antibiotic used to treat typhoid fever.

This primary health care also uses azithromycin and cefixime, which is not included in the list of drugs in Indonesian national formulary for the FKTP but is included in the list of drugs in the 2007 Basic Care Health Center Guidelines. Based on an interview with the chief pharmacist, azithromycin and cefixime used were prescribed mainly for bacterial sexually transmitted infections (STIs) from polyamorous relationships. These results are consistent with the 2007 Basic Care Health Center Guidelines because azithromycin is one of the treatment options for patients suffering from STIs, such as chlamydiasis, and cefixime is one of the drugs for patients with gonorrhea. Based on the Decree of the Directorate General of Pharmaceuticals and Medical Devices regarding the implementation of the 2014 Indonesian national formulary, drugs not included in the Indonesian national formulary list for the FKTP can be used if they are in accordance with medical indications and medical service standards

\section{CONCLUSION}

The antibiotics used in 2018 by patients at Kebayoran Baru Primary Health Care were amoxicillin, ciprofloxacin, cefadroxil, erythromycin, thiamphenicol, metronidazole, azithromycin, cotrimoxazole, cefixime, and doxycycline. The total number of the top three antibiotics used was amoxicillin at $0.9358 \mathrm{DDD} / 1000$ inhabitants/d, ciprofloxacin at $0.4940 \mathrm{DDD} / 1000$ inhabitants/d, and cefadroxil at $0.1983 \mathrm{DDD} / 1000$ inhabitants/d. The most commonly used antibiotics that are included in the DU 90\% segment were amoxicillin, ciprofloxacin, cefadroxil, and thiamphenicol. There was 70\% conformity of antibiotic use in 2018 at Kebayoran Baru Primary Health Care with Indonesian national formulary for the FKTP.

\section{ACKNOWLEDGMENTS}

The authors would like to thank the Kebayoran Baru Primary Health Care for providing permission and data for this study.

\section{CONFLICTS OF INTEREST}

The authors declare that they have no conflicts of interest.

\section{REFERENCES}

1. Penesyan A, Gillings M, Paulsen IT. Antibiotic discovery: Combatting bacterial resistance in cells and in biofilm communities. J Mol 2015;20:5286-98.

2. World Health Organization; 2018. Available from: https://www.who. int/news-room/fact-sheets/detail/antibiotic-resistance.

3. Ministry of Health Republic of Indonesia. In: Regulation of the Minister of Health of the Republic of Indonesia No 2406/Menkes/PER/XII/2011 about General Guidelines for using Antibiotics Jakarta, Indonesia. Jakarta, Indonesia: Ministry of Health Republic of Indonesia; 2011.

4. Suwarto S. Penyakit tropik dan infeksi pada abad 21: Apakah masih relevan? J Penyakit Dalam Indones 2014;1:15.

5. Ministry of Health Republic of Indonesia. The Main Result of Basic Health Research (RISKESDAS 2018). Jakarta: Ministry of Health Republic of Indonesia; 2018.

6. Hasrianna H, Annisa N, Milanda T, Pradipta IS, Abdulah R. Monitoring the use of antibiotics by the ATC/DDD and DU90\% at RSUD Abepura Jayapura, Indonesia. J Farmasi Klin Indones 2015;4:218-25.

7. Fleming-Dutra KE, Hersh AL, Shapiro DJ, Bartoces M, Enns EA, File TM Jr., et al. Prevalence of inappropriate antibiotic prescriptions among US ambulatory care visits, 2010-2011. JAMA 2016;315:1864-73.

8. Ministry of Health Republic of Indonesia. In: Hospital Antimicrobial Resistance Control Program Program Pengendalian Resistensi Antimikroba di Rumah Sakit. Jakarta, Indonesia: Ministry of Health Republic of Indonesia; 2015.

9. World Health Organization. Introduction to Drug Utilization Research. Oslo: World Health Organization; 2003.

10. Ministry of Health Republic of Indonesia. Regulation of the Minister of Health of the Republic of Indonesia Number 74 in 2016 Concerning Pharmaceutical Service Standards at Public Health Care Center. Jakarta, Indonesia: Ministry of Health Republic of Indonesia; 2016.

11. World Health Organization Collaborating Centre for Drug Statistics Methodology. Use of ATC/DDD. Guidelines for ATC Classification and DDD Assignment 2019. Oslo: World Health Organization Collaborating Centre for Drug Statistics Methodology; 2019. Available 
from: https://www.whocc.no/use of atc ddd.

12. Pradipta IS, Ronasih E, Kartikawati $\bar{A}$, Hartanto H, Amelia R, Febrina E, et al. Three years of antibacterial consumption in Indonesian community health centers: The application of anatomical therapeutic chemical/defined daily doses and drug utilization $90 \%$ method to monitor antibacterial use. J Family Community Med 2015;22:101-5.

13. Pradipta IS, Febrina E, Ridwan MH, Ratnawati R. Identifikasi pola penggunaan antibiotik sebagai upaya pengendalian resistensi antibiotic. J Farmasi Klin Indones 2012;1:16-24.

14. Syahidah AZ, Andrajati R, Puspitasari AW. Evaluation of anti-infectives on acute respiratory infection in patients at three primary health cares centres in Depok, Indonesia. J Young Pharm 2017;9:s35-8.

15. Plet HT, Hallas J, Kjeldsen LJ. Adherence to hospital drug formularies and cost of drugs in hospitals in Denmark. Eur J Clin Pharmacol 2013:69:1837-43

16. Sholih MG, Muhtadi A, Saidah S. Rasionalitas penggunaan antibiotik di salah satu Rumah Sakit Umum di Bandung tahun 2010. J Farmasi Klin Indones 2015;4:63-70.

17. Gillies M, Ranakusuma A, Hoffmann T, Thorning S, McGuire T, Glasziou P, et al. Common harms from amoxicillin: A systematic review and meta-analysis of randomized placebo-controlled trials for any indication. CMAJ 2015;187:21-31.

18. Sharma PC, Jain A, Jain S, Pahwa R, Yar MS. Ciprofloxacin: Review on developments in synthetic, analytical, and medicinal aspects. J Enzyme Inhib Med Chem 2010;25:577-89.

19. Pani S, Barliana MI, Halimah E, Pradipta IS, Annisa N. Monitoring penggunaan antibiotik dengan metode ATC/DDD dan DU 90\%: Studi observasional di seluruh Puskesmas Kabupaten Gorontalo Utara. J Farmasi Klin Indones 2015;4:275-80

20. Mahmudah F, Sumiwi SA, Hartini S. Studi penggunaan antibiotik berdasarkan ATC/DDD dan DU 90\% di bagian bedah digestif di salah satu Rumah Sakit di Bandung. J Farmasi Klin Indones 2016;5:293-8. 